\title{
Author Meets Critics
}

\author{
Sarah M. Stitzlein \\ University of Cincinnati
}

\section{AN INTRODUCTION TO LEARNING HOW TO HOPE}

Democracy is struggling in America and citizens are struggling too. It's a good time to be talking about hope, as we move toward a presidential election and as we deal with continued fallout of transitioning from one presidential era to the next, marked in 2008 and 2016 by significant shifts in how our polarized citizenry experiences hope and despair. During the 2008 presidential campaign, Barack Obama had the audacity to hope. Although I had been a long time Republican and was then in a new courtship with Democrats, I was swept up in that hope. From our couches, many of us happily endorsed Obama's "hope" campaign slogan. Some affirmed the message by donning now famous Hope t-shirts. But within a few months, doubt set in and I took my seat back on the couch, naively content to believe that things would get better. At the end of his presidency and on the heels of a contentious election in 2016, many of us, especially on the Left, wonder, "what happened to hope?" While at the same time, some of the Right who celebrated Trump's election, including some of those in in my large Ohio farming family, are sensing that their hopes may not be fulfilled.

The problem is that the form of hope we boast on campaign materials and in election year conversations doesn't involve sustained action. During the campaign, hope was pretty passive for most of us who simply supported our candidates from our couches. A person had hope but didn't do anything about it beyond casting a ballot, or perhaps writing a check or volunteering for a campaign, at best. Now, in the midst of a contentious election year in 2020, we don't need a "reason" to hope, but we need guidance on how to hope, where hope is more like a verb-an action that we do together as citizens, rather than something that we possess as individuals or something that we entrust in messianic leaders like Obama or Trump. This is what led me to write Learning 
How to Hope: Reviving Democracy through School and Civil Society. In the book, I explain what hope is, why it matters to democracy, and how to teach it. And, in the democratic spirit of communal knowledge and working together through challenging political times, I released the book as a free, open access publication through Oxford University Press.

The book begins by describing the contemporary political landscape in America, where political despair is growing. To make sense of these conditions and their historical trajectory, I turn to the American roots of pragmatist philosophy to show how that tradition aligns with key elements of democracy and struggles in American life today. It describes problematic ways in which hope is often understood as an individualist emotional outlook. Then, it lays out central elements of pragmatism that form an account of hope that is social and political, where hope is a set of habits that we develop through our interactions with other people, including in schools.

I draw upon John Dewey to explain how hope grows out of our inquiry into the world around us as we seek to resolve what he calls, "indeterminate situations." Hope often arises within the midst of despair, when we have lost our way and are struggling to move forward. When these moments occur, we should turn to the process of inquiry via the empirical method to help us explore those situations, consider possible courses of action, and test out various solutions. Inquiry is related to growth. We grow when we apply what we learn from inquiry and create ways to smoothly move from one activity to the next. We develop what Dewey calls "ends-in-view," which are relatively close and feasible goals that help us move forward out of the ruts we face in life and out of moments of despair.

Then I turn to Dewey's idea of meliorism as a practical way that we can move forward in difficult times. Meliorism holds that there is significant evidence in history to show that we can make things better through effort and work together. Such efforts are rarely undertaken alone, instead they are tied to others who are working together to solve problems. Meliorism is not a belief in inevitable progress, but rather a call to human action, especially in the midst of struggle and uncertainty. In the book, I piece together inquiry, growth, and meliorism, to offer an account of hope where hope is a set of habits-a disposition 
toward possibility and change for the betterment of oneself and, often, others. Hope is something that we do. Many citizens today tend to proclaim whether they do or do not "have hope," as though hope is an object that is possessed, often passively, as if we merely hold it or lose it. Pragmatist habits of hope, however, are better understood as a verb—hoping, an ongoing activity. Hope, then, is an inclination to act. It entails thinking imaginatively about our challenging situations and working with others to change and improve them. Hope matters to democracy because shared hoping, and the content of what we hope for, ties communities together. Hoping with others for the same goals entails a joint commitment that gives our connections substance and direction. I argue that this sort of problem-solving and collective citizen behavior can greatly help us today, where we see citizens increasingly siloed into like-minded political groups, and unable to trust or work with others.

Next in the book, I talk about hope in terms of our current political environment. I argue that counter to the rosy image of hope, it is not all about happiness. If we look outside in America right now, we see a lot of upset people taking to the streets in protest. This is a sign that democracy is alive, but I think it could be improved if we better connected hope and dissent. Perhaps counterintuitively, hope can lead to dissent because, when we focus on the improved future we desire, we may find ourselves dissatisfied and frustrated with how things are now. That discontent can be used proactively as democratic dissent. In such dissent one not only expresses one's dissatisfaction with the current state of affairs, but helps others to see the problem, and then puts forward solutions to be discussed and tested. Dissent enables struggling citizens to name problems, call for collective work, and engage in action, rather than resigning to the negativity and paralysis of despair.

Recognizing that hope is not inherent in our lives, but rather requires cultivation, I close the book with suggestions for how we might teach hope in schools and in civil society. I especially make effort to differentiate teaching hope from teaching grit. I argue that this widely-celebrated approach is not a good way to improve our political or individual lives. Indeed, it may even exacerbate political despair as it leaves systems of injustice in place and further frustrates citizens who are urged to face them alone. Instead, I offer a call for citizenship 
education that is social, deliberative, and engaged with community problems. To nurture habits of hope, I call for schools to develop communities of inquiry, nurture communication and deliberation, foster criticality and dissent, cultivate imagination and storytelling, view citizenship as shared fate, and build trust. I extend this discussion of education for hope into suggestions for adults and civil organizations, where larger impact on today's democracy may be made.

I am grateful to my critics for taking up my work so carefully and for offering helpful suggestions for my ongoing project of reviving democracy and improving civic engagement, which extend beyond this book. I begin here by responding first to the more general concerns of Winston Thompson, then move into considering the ambiguities raised by Derek Gottlieb, before closing with a look at some of the more particular aspects of religious views of hope posed by Clarence Joldersma.

\section{REASONS TO RESIST HOPE}

To begin, Thompson's critique pushes me to more clearly foreground a key aspect of hope and its benefits. Perhaps "the by-product of hope" that interests me, to use Thompson's term, is not so much a by-product at all, but rather an essential element of hope that is often lacking in other accounts: action. Indeed, it is this sense of hope as a verb - a doing — that distinguishes my account from others. This aspect underlies much of my response to his criticisms.

Thompson asks whether hope is compelling. I, in turn, ask what keeps something from being compelling? Sometimes things aren't compelling because we are resistant to them, and not just hesitant to them, as Thompson describes himself. Whereas hesitancy is often related to uncertainty, resistance is more connected to principled reasons. Which leads me to ask why he might be resistant? Perhaps his reasons stem from the ways that other forms of hope (such as political slogans) have been problematically used in the past to dupe or pacify citizens. Or, perhaps it may be that hoping has been too exhausting for some people over time. I suspect that what I face here is not a critic who just needs to be urged past hesitation, but rather someone who may have legitimate reasons for being skeptical or resistant. 
The first of those reasons relates to concerns that hope may obscure our ability to fully see and understand the complete reality of our situationperhaps that a focus on a better future may prevent us from understanding just how bad the present is and the past circumstances that brought us to this point. I do think Thompson is correct that hope has been wielded in this way in the past, perhaps especially as a political slogan. But it's important to note that I situate my hope within pragmatism. This is a tradition where we don't just employ a cursory account of the past and present, but rather one where we inquire deeply into those circumstances as sources for helping us understand our indeterminate situations, inquire into how we can use the best of the past to move forward, reconstruct ourselves and our environment, and then test out our solutions within the present. I'm suggesting a deeply situated account of hope, not blind optimism, as I distinguish in the book. ${ }^{1}$ Nonetheless, I do recognize that becoming overly focused on the future may narrow our vision in ways that keep us from fully seeing or appreciating the problems of the present. Perhaps, then, I need to work harder to develop a bifocal account of hope that more overtly engages in moving between different points of focus from what is immediately present and what might be in the future, seeing each in light of the other. ${ }^{2}$ And I need to emphasize, once again, the active component of this sort of hope, one that is always on the lookout for blind spots, myths, and other distractions that keep one from fully experiencing reality in the ways that concern Thompson.

The second and third reasons Thompson gives assert that hope may not be essential for civic engagement, but rather it may be a luxury. These reasons lead him to suggest the possibility of non-hopeful citizens. Perhaps we may be witnessing some of those sorts of citizens active in protests against racism and police brutality today. They may not be hoping for a better future where equity is achieved, perhaps because, like Ta-Nehisi Coates, they see that outcome as largely impossible. ${ }^{3}$ Yet, they may feel that it's appropriate for them to do something about the injustice evident today and that civic action through protest is the best way to engage right now. While I'm willing to concede that hope may not be essential for civic engagement, as Thompson suggestions, I 
contend that it can provide motivation to start civic engagement, help sustain citizens through the struggles of ongoing engagement, and help unite citizens with others in ways that build solidarity and coalitions that are useful for achieving civic ends. In other words, I think civic action is likely improved and more sustainable when propelled by hope.

This leads into my response to Thompson's final concern that my argument for hope, when recognizing that it might not be the best for all people in all situations, may be unsatisfactory. Yes, the fact that hope may not always be the best or even a desirable approach does call into question my resulting appeal to teach hope universally in schools and civil society. But, I believe I am justified in doing so because budding citizens must be equipped with the capacity to hope (via habits, skills, and know-how) so that when circumstances provoke or are amenable to hoping, citizens are ready to engage in hoping. To deny such an education would be to foreclose opportunities for more sustainable civic participation in the future.

I suggest that Thompson's final question regarding whether there might be times when we should not teach hope can be altered slightly to offer a friendly amendment to my project. Teachers and civic leaders must talk with students about the limits and suitability of hoping for all people and in all situations, helping them to recognize that while hope has significant benefits for collective public life as a whole, there may be times when it is not well suited for individuals or particular communities. In pragmatist spirit, students might then learn about alternatives they could experiment with in those situations, including forms of resistance or even dutiful obligation to participate. Indeed, these may be some of the many multiple motivators for civic engagement that Thompson seeks in schools. Even though I am open to these possibilities, however, I want to be clear that I still strongly side with the effectiveness of hoping for civic renewal as suitable for nearly all educational settings.

\section{ADDRESSING AMBIGUITIES}

Like Thompson, I appreciate that Gottlieb also challenges me to address some of the ambiguities in my account that leave open the very sorts of 
questions that Thompson poses. Gottlieb pushes me to look more closely at how we actually enact our habits as ourselves and how our habits may relate to our failures to communicate well and to alleviate racism. This is due, in part, because we fail to sufficiently first set the stage for communication and because we may actually limit the types of communication employed. And while he largely traces the source of those ambiguities to tensions in Dewey, I bear some responsibility for the way that I have uncritically employed them.

I want to follow Gottlieb in the concerns he raises about the hypothesis view of tentatively holding habits. Indeed, if we were to hold habits tentatively, we would lack a sense of self that enables us to traverse the world with relative ease and offers us a relatively stable basis for our perceptions, judgments, and actions. Enacting habits in a more stable way, however, should not be seen as the sort of dogmatist closure that heads off critical reflection. Despite Dewey's potential inconsistencies on this issue, let me return to his words briefly. $\mathrm{He}$ claims, "[a]ll habits are demands for certain kinds of activity; and they constitute the self." " There is no complete person behind the habit who is able to choose which habit to enact and when, as if habits were merely a hypothesis distinct from oneself that can simply be objectively tested. People do not use habits at will because they do not preexist them. "The use itself is the habit, and 'we are the habit."'5 Dewey, here sounding as though a forerunner of poststructural theories of subjectivity and performativity, depicts habit as simultaneously produced, performed, and constitutive. Moreover, the "we" he describes are not fixed beings but rather subjects in the process of becoming. We do embody our habits in ways that are more deep and persistent than just hypotheses. Yet, I want to emphasize the Deweyan spirit of holding ourselves open to change when an indeterminate situation presents itself and our habits are no longer serving us well—when the record scratches, as Gottlieb rightly describes. It's in those moments that our habits call us out and, for the open and flexible person, can usher in transformation in ourselves, including our habits and beliefs. It's this sort of transformation that I detailed in my first book, Breaking Bad Habits of Race and Gender: Transforming Identity in Schools. ${ }^{6}$

These concerns then set Gottlieb up to make an interesting analysis 
of Afro-pessimism which reveals its "meliorative commitment to struggle," as Gottlieb describes it. Perhaps there is more similarity between my pragmatist account and Afro-pessimists than I first detected. Gottlieb describes how Afro-pessimists see racist structures as prior to our conceptual apparatus. To put that back in the context of Dewey's account of habit formation, those racist structures become part of the social web that influences how our habits are shaped and even interpreted, constraining them in problematic ways. Whereas Gottlieb points to Calvin Warren's view as not being hopeless about achieving racial justice, but rather recognizing the much more difficult struggle we must first undertake to dismantle those constraints. And that puts the onus back largely on white people who have perpetuated and benefited from many of them.

To push against Dewey a bit, many years of complacency show us that not enough white people have been attuned to the record scratching for themselves or for others. They haven't encountered those racist structures as problems. We cannot just wait for those moments to reveal themselves. And perhaps that's where the pessimism comes in; some Afro-pessimists feel that's just never going to happen. I contend, however, that with some heavy lifting and conscious criticality, we can start to recognize and reconstruct those racist constraints, thereby changing our conceptual apparatuses to enable us to become something different, something non-racist. Gottlieb then closes with precisely the sort of call that comes across in my collective work, for educative experiences that better position students to be critical of the influences on their habits, to enable students to more genuinely listen to others, and to change themselves as a result of those reflections and encounters.

\section{RELIGIOUS ASPECTS OF HOPE}

Finally, I turn to the more particular challenges posed by Clarence Joldersma. Initially, I was a bit struck by what appeared to be a narrow focus in Joldersma's critique of my book, as it grows out of one small paragraph early in the book where I distinguish my pragmatist hope from the hope upheld by some popular theologians. ${ }^{7}$ But, I've come to see that he is actually raising larger issues that span the book. In that paragraph, I am rather quick to set aside accounts of hope based in theology because they largely entail handing 
over agency to a god that acts on one's behalf. But, by so quickly writing off the hope advanced in some religions, I also foreclose the engagement with my work of a significant population of America who does not distinguish their religion from their lives as citizens. This may also foreclose their willingness to participate in democracy if setting aside their hope based in religion were to be some sort of prerequisite. I do not wish for that to be the case.

Recognizing the contrasts between my idea and religion (noun), Joldersma wisely distinguishes the religious (adjective) spirit and sees it operating in my work. Insofar as my project is concerned with moving past our current flawed democracy toward the possibility of something better, I can see affinity between my generative, imaginative hope and the sort of religious spirit that Joldersma ascribes to Dewey, which aims to move "beyond the actual into what is possible," to quote Joldersma. In "What I Believe" and A Common Faith, Dewey distances religious spirit from supernatural figures and instead emphasizes the religious-like intensity of devotion to the power of people working together and conviction in the persistence of people to try. Dewey's faith is embodied in a "tendency toward action." my own and are reflected in my use of meliorism and my call for cultivating democratic habits as a proclivity toward action. Moreover, Joldersma reveals that there is much we can learn by considering the religious aspects of pragmatists like John Dewey, George Herbert Mead, and Cornel West, including how to better understand the practice and improvement of democracy.

While I am willing to experiment with the religious spirit invoked by Dewey and West, I am hesitant to firmly ground that spirit in religion, as West does. Dogma, doctrine, and tradition, especially pronounced in religions other than Protestant ones described by Joldersma, lack the adaptability that I find essential to leading a life based in inquiry that allows for growth, especially when I see dissent as key to facilitating change and the improvement of life's conditions. Religions that silence or ignore such dissent, or that find dissent a challenge to their authority rather than a practice of affirming their legitimacy, are irreconcilable with the participatory democracy that I envision. That said, I recognize that perhaps the Protestant and Calvinist denominations that he em- 
phasizes might be more aligned with my views and may see collectivity working toward improved living as akin to "the realization of the kingdom of God," even if I do not. I am more willing to endorse the particularism of reformed Protestantism, which doesn't try to universally apply orthodoxy and remains, instead, focused on the particular congregation, or more to my topic, groups of citizens, and their needs and desires.

Where I do draw the line is with his suggestion that my view of hope echoes postmillennialist thought. Like Dewey, my naturalist tendencies leave me skeptical of accounts of salvation, like that espoused by postmillennial supporters. Responding to Joldersma's assertion of similarity, I do not support the sense of American exceptionalism inherent in postmillenialism. Though I favorably quote Colin Koopman in the book, who highlights the distinct nature of hope and democracy in America, I feel that Joldersma reads Koopman's quotes on to me, arriving at a stronger stand than I actually take. While I do trace the American "spirit" to roots in pragmatism and suggest that pragmatism offers a fitting orientation for helping us attend to problems in our democracy today, I do not hold that America is somehow special in its quest to or likelihood of achieving better life conditions or democracy. And, while I celebrate the ways in which American citizens have combined vision and action, which are integral to hoping, such an outlook on democracy can and has been forged in other countries. And, while I ground the social imaginary I speak of in the context of America, that is not to say that I believe America is exceptional, I'm simply attending to the challenges of political life in the current place where I live. Moreover, I'm drawing on America's own historical philosophical traditions as a source for its future. Yet, I do recognize that hope finds more fertile ground in America, its history, its values, and the general outlook of its citizens than in some other countries that embrace what their citizens may call "realism," or are more skeptical about the abilities of citizens to improve life's conditions.

Postmillennialism also seems to uphold a predetermined end goal: to prepare for and bring about the kingdom of God by making America suitable for His reign. Even if my account of hope echoes postmillennial views, I do not subscribe to a fixed end, nor do I subscribe to some ultimate meaning apart 
from, as Dewey explains, the ways in which we "wrest from each changing situation of experience its own full and unique meaning." In fact, one of the things that I emphasize about the role of hope in a democracy is that it is continually enacted to reimagine our future, which may take many different forms and is not limited to a particular trajectory, rather the needs and desires of the citizenry as they adapt to their world form and reshape their goals. Yes, I do celebrate future-directed meliorism, as Joldersma claims, but I do so not because I hold out some predetermined end for human effort or some point of turning the reins back over to God. Rather, I leave agency and the creation of goals in the hands of citizens. In sum, I appreciate the connections Joldersma draws, even if I find some to be faulty, because they push me not to cut short religious views on hope and to consider how they might actually be foregrounded as sources of democratic initiative.

I am grateful to my critics and their helpful suggestions, which will surely contribute to my ongoing efforts of reviving democracy and improving citizen engagement through education.

1 Sarah M. Stitzlein, Learning How to Hope: Reviving Democracy through Schools and Civil Society (New York: Oxford University Press, 2020), 22. The complete, free, open access text can be accessed at https://global.oup.com/academic/ product/learning-how-to-hope-9780190062651?q= stitzlein\&lang=en\&cc=us 2 Kathleen Knight Abowitz describes the use of a bifocal approach in a different context, though one still related to civic engagement in Publics for Public Schools (Boulder, CO: Paradigm Press, 2013).

3 Ta-Nehisi Coates, Between the World and Me (New York: Spiegel and Grau, 2015).

4 John Dewey, Human Nature and Conduct in John Dewey: The Middle Works, 1899-1924, vol. 14, ed. JoAnn Boydston (Carbondale: Southern Illinois Uni- 
versity Press, 1983/1922), 21.

5 Gert Biesta and Nicolas C. Burbules, Pragmatism and Educational Research

(Lanham, MD: Rowman \& Littlefield, 2003), 38, quoting Dewey 1922 p. 21.

6 Sarah M. Stitzlein, Breaking Bad Habits of Race and Gender: Transforming Identity in Schools (Lanham, MD: Rowman \& Littlefield, 2008).

7 Stitzlein, Learning How to Hope, 21.

8 John Dewey, What I Believe in John Dewey: The Late Works, 1899-1924, vol. 5, ed. Jo Ann Boydston (Carbondale: Southern Illinois University Press), 267. 9 John Dewey, What I Believe, 272. 